\title{
SOCIALNI KAPITAL NA SLOVENSKEM PODEŽELJU
}

\author{
dr. Irma Potočnik Slavič \\ Oddelek za geografijo, Filozofska fakulteta Univerze v Ljubljani, \\ Aškerčeva 2, SI-I000 Ljubljana \\ e-mail: irma.potocnik@ff.uni-lj.si
}

Izvirni znanstveni članek

COBISS 1.01

\section{Izvleček}

$\mathrm{V}$ zadnjih dveh desetletjih je postal koncept socialnega kapitala zelo priljubljen tako med raziskovalci kot v politični praksi. Njegovo merjenje je kljub relativno preprostemu in navidezno uporabnemu konceptu zelo težavno. Analiza kazalcev socialnega kapitala na izbranih območjih slovenskega podeželja (Zgornja Savinjska dolina, Suha krajina, Goriška brda, Brkini) je pokazala njegov pozitivni učinek za lokalne skupnosti, kar je predpogoj za aktiviranje endogenih razvojnih potencialov.

Ključne besede: podeželje, socialni kapital, Zgornja Savinjska dolina, Suha krajina, Goriška brda, Brkini, Slovenija

\section{SLOVENIAN RURAL AREAS AND SOCIAL CAPITAL}

\begin{abstract}
In the last two decades, the concept of social capital has become very popular amongst researchers and in politics as well. Its measurement is very complex in spite of relatively simple and apparently useful concept. Analysis of social capital indicators in selected Slovenian rural areas (Upper Savinja Valley, Suha krajina, Goriška brda, Brkini) have demonstrated its positive impact on local community capacity building, being the starting point for activation of endogenous development potentials.
\end{abstract}

Key words: rural areas, social capital, Upper Savinja Valley, Suha krajina, Goriška brda, Brkini, Slovenia 


\section{UVOD}

Od začetka devetdesetih let 20. st. je med akademsko in politično sfero prisotna široka razprava o socialnem kapitalu, zlasti glede njegovega prispevka pri pojasnjevanju razlik v družbenem, političnem in gospodarskem razvoju. V povezavi s preučevanjem njegove vloge na slovenskem podeželju je potrebno izpostaviti, da:

- je koncept socialnega kapitala, ki se pogosto uporablja v sociologiji, političnih vedah in regionalno-razvojnih študijah, relativno nov, večplasten, nestvaren in nenatančen (Mohan in Mohan 2002; Mandl in sod. 2007);

- $\quad$ se koncept socialnega kapitala večinoma uporablja pri pojasnjevanju neenakomernega razvoja (na različnih ravneh), vrednotenju učinkov politik in pojasnjevanju prostorskih razlik v zdravstveni praksi;

- je glavni problem sodobnega raziskovanja socialnega kapitala njegovo merjenje;

- so zaenkrat precej redke raziskave socialnega kapitala na mikrolokalni ravni (Svendsen in Sørensen 2007; Foissner 2000); te so prostorsko omejene in specifične, vendar dajejo boljši vpogled v delovanje mikrosistema;

- obstajajo dovolj prepričljivi argumenti za razmislek o geografiji socialnega kapitala.

Navedena izhodišča predstavljajo teoretsko-metodološki okvir raziskave socialnega kapitala na slovenskem podeželju, in sicer njegove vloge pri razvoju lokalnih skupnosti v Zgornji Savinjski dolini, Suhi krajini, Goriških brdih in Brkinih. S podrobno raziskavo na obrobnih podeželskih območjih želimo razbrati glavne dejavnike, ki vplivajo na razvoj socialnega kapitala in aktiviranje endogenih razvojnih potencialov.

\section{KONCEPT SOCIALNEGA KAPITALA}

Za Colemana (1988; citirano po Mohan in Mohan 2002), ki ga večina raziskovalcev označuje kot začetnika konceptualizacije socialnega kapitala (Janc 2006), je socialni kapital zmožnost ljudi za skupno delo v okviru skupin, ki želijo uresničiti skupni namen. Te zmožnosti so večinoma rezultat medosebnega zaupanja, družbenih pravil in mrež. Tako je socialni kapital nevidni vir, vključen v odnose med ljudmi in tako kot druge oblike kapitala (finančni, človeški, okoljski itn.) vpliva na gospodarske dejavnosti. Pravila in mreže se po Putnamu (1993), najbolj odmevnem teoretiku socialnega kapitala, oblikujejo z vključevanjem v različne oblike društvene dejavnosti. Za razliko od večine dobrin se socialni kapital z uporabo ne izrabi, nasprotno, socialni kapital se z uporabo povečuje; čeprav to ne pomeni, da se ne more izčrpati zaradi nerabe ali neustrezne rabe. Moseley (2003) trdi, da socialni kapital določa zmožnost lokalnega prebivalstva in ustanov za učinkovito skupno delovanje na lokalni ravni. Za razvoj socialnega kapitala na podeželju so zlasti pomembni obstoječa društva, klubi, zadruge, razširjene družine, sindikati, podjetniška združenja, trgovske zbornice in politične stranke, kot tudi vladne ustanove na lokalni ravni.

Parissaki in Humphreys (Mandl in sod. 2007) sta opredelila tri vrste povezav med ljudmi:

- povezovanje (ang. bonding): povezave z, oziroma znotraj ozkega socialnega okolja (družina, prijatelji, sosedje), ki temelji na medosebnem zaupanju med znanci; 
- mostiščenje (ang. bridging): mreže horizontalnih zvez, povezane z medosebnim zaupanjem med tujci;

- $\quad$ prepletanje* (ang. linking): vertikalne povezave, ki temeljijo na institucionalnem zaupanju v javne in zasebne ustanove (* prevod smatramo kot 'delovno' inačico, ker zaenkrat še nismo našli ustreznega poimenovanja).

Opredelitev Evropske komisije posnema Colemana, a ga pomembno dopolnjuje: od socialnega kapitala namreč pričakuje uporaben rezultat za skupno dobrobit vseh vključenih. Falk in Kilpatrick (2000; citirano po Mohan in Mohan 2002) dodajata še geografsko razsežnost, ko govorita o socialnem kapitalu kot zgostitvi družbenih interakcij posameznikov na mikro ravni, ki so vključeni v makro družbeni red skupnosti. Tudi Miller in Calhoun (1996; citirano po Mohan in Mohan 2002) poudarjata regionalni koncept: socialni kapital je vedno trenutni posnetek stanja in se ne prenaša enostavno med generacijami, ampak se stalno spreminja.

Precej je prisotno mnenje (npr. Janc 2006), da se koncepta socialnega in človeškega kapitala (pa tudi kulturnega in organizacijskega; Svendsen in Sørensen 2007) medsebojno dopolnjujeta pri pojasnjevanju prostorske raznolikosti družbeno-gospodarskega razvoja. Spet drugi trdijo, da je mogoče socialni kapital ločiti od človeškega kapitala, ker naj bi človeški kapital označeval lastnost oziroma sposobnost posameznikov v obliki veščin ali zmožnosti, ki jih izkazujejo pri opravljanju nalog. Ostrom (2000; citirano po Mohan in Mohan 2002) pravi, da se lahko socialni kapital razvije kot stranski proizvod drugih aktivnosti v skupnosti, medtem ko se človeški kapital ustvarja preko bolj namenskih naporov posameznikov.

Pri preučevanju socialnega kapitala je potrebno razlikovati med dvema vidikoma: med čvrstimi medpodjetniškimi odnosi (zlasti so jih preučevali ekonomski geografi; Mohan in Mohan 2002) in med mrežami društvenega življenja, ki so privlačile Putnamovo (1993) zanimanje.

Iz obstoječe relativno obsežne in novejše literature je mogoče razbrati tri glavna področja, kjer se uporablja koncept socialnega kapitala: pri pojasnjevanju neenakomernega razvoja na različnih ravneh, primerjanju učinkov politik in pojasnjevanju prostorskih razlik v zdravstveni praksi.

Socialni kapital se uporablja pri pojasnjevanju gospodarske rasti in neenakomernega razvoja. Tovrstne raziskave večinoma temeljijo na hipotezi, da so države z visokim socialnim kapitalom običajno finančno bogatejše (merjeno z BDP na prebivalca) ali izkazujejo hitrejšo gospodarsko rast. Nekateri modeli (Halpern 1999; citirano po Mohan in Mohan 2002) kažejo, da je socialni kapital za gospodarsko rast pomembnejši kot človeški kapital: socialni kapital namreč dviguje zaupanje, kar znižuje stroške, saj se zmanjšuje potreba po dragih pogodbenih dogovorih in spodbuja prenos informacij. Socialni kapital je lahko učinkovit tudi pri pojasnjevanju med- in znotrajdržavnih procesov neenakomernega razvoja. Raziskave (npr. Mohan in Mohan 2002) so poskušale odkriti razloge, zakaj določena območja 'delujejo bolje' kot druga. Rezultati so običajno nakazovali institucionalni splet, ki omogoča mreženje in spodbuja zaupanje, promovira izmenjavo idej in stikov, izpostavlja zmožnost območja za inovacije in prepoznavanje identitete. Na novih industrijskih območjih so ugotovili, da se znanje med podjetji izmenjuje na osnovi neformalnih pravil in dogovorov 'na štiri oči'. 
Socialni kapital se uporablja pri pojasnjevanju zdravstvenih neenakosti zaradi dejstva, da na tem področju kljub rastočemu življenjskemu standardu obstajajo pomembne razlike. Jedro preučevanja se je usmerilo $\mathrm{k}$ stopnjam neenakosti med in znotraj držav s predpostavko, da so v državah z višjo stopnjo socialne blaginje razlike v zdravju manjše in splošne stopnje zdravja višje (Mohan in Mohan 2002).

Največ kritik koncepta socialnega kapitala se osredotoča na dejstvo, da ne vemo, kako se socialni kapital oblikuje. Obstaja dvom, ali se socialni kapital res proizvaja izključno le preko tistih vrst dejavnosti, ki jih izberemo kot kazalce in jih preučujemo. Putnam (1993) je npr. trdil, da se socialni kapital proizvaja z vključevanjem prebivalcev v številne prostovoljne društvene aktivnosti, preko katerih posamezniki srečajo svoje kolege v enakovrednih pogojih in se naučijo medsebojno delovati in zaupati. Kritike se nanašajo tudi na (Putnamove) načine merjenja vključenosti. Ali je vključenost že to, da se posameznik vpiše v neko društvo in plača članarino? Po drugi strani naj bi neposredna vključenost s fizično prisotnostjo v sedanjem kibernetskem prostoru izgubljala na pomenu. Dejstvo je, da niso vsa društva enako organizirana, niso vsa odprta vsem in da se jim ljudje lahko priključijo zaradi zelo različnih vzrokov. Tako kot motivi so različni tudi pogoji vključevanja.

Kritizira se tudi Putnamovo dokaj enostransko gledanje glede lastnosti socialnega kapitala, saj poudarja njegove pozitivne lastnosti, medtem ko zapostavlja negativno stran. Rubio (1997; citirano po Mohan in Mohan 2002) se nanaša na sprevrženi socialni kapital (ang. perverse social capital), t.j. kriminalne tolpe ali organizirani kriminal, ki tudi vključuje glavne značilnosti Putnamove konceptualne triade (mreže, pravila, ukrep). Lahko pride tudi do stanja, ko imajo konkurenčne družbene skupine visoke stopnje socialnega kapitala znotraj skupine, ampak zelo nizek socialni kapital med posameznimi skupinami. Putnam zapostavlja načine, po katerih se lahko oblikuje (ali uniči) socialni kapital. Večina kritik je osredotočenih na njegovo podcenjevanje vloge države (velika večina društvene dejavnosti v Sloveniji je podprta s strani vlade in/ali občinskih struktur) pri spodbujanju društvenega življenja in razvoju socialnega kapitala. Danes se kritiki Putnamovih izhodišč sprašujejo o smeri vzročnosti in odvisnostih med državo in prostovoljnimi organizacijami. S tega vidika bi bila dobra vlada lahko vzrok ali posledica visokega socialnega kapitala. Sodobni teoretiki se izmikajo tem vprašanjem; odnosi med vlado in društvi naj bi se vzajemno krepili (npr. v raznovrstnih partnerstvih).

\section{METODOLOŠKA IZHODIŠČA}

Poleg jasne konceptualne utemeljitve in njegove uporabnosti je glavni problem sodobnega raziskovanja socialnega kapitala njegovo merjenje. Podatkov o razsežnostih socialnega kapitala popisi prebivalstva ne zbirajo, zato moramo vključiti neposredne ali posredne meritve. Putnamov vzročni model predlaga vključenost prebivalcev v aktivnosti društev kot kazalec razvitosti socialnega kapitala. Kar precej avtorjev je sledilo njegovemu napotku: uporabljali so podatke o društveni aktivnosti kot približku socialnega kapitala. Društvene statistike so za nekatere ključne organizacije dostopne za daljše časovne vrste. Občasno so tovrstni podatki celo zavajajoči zaradi sprememb v značaju društvenega življenja. Ključnega pomena pa so motivi posameznika za vključevanje. Če merimo vključenost ali zaupanje, nastopijo težave s 
pridobivanjem neagregiranih podatkov. Zato se raziskave večinoma izvajajo na ravni držav, obstaja tudi kar nekaj mednarodnih raziskav (Mohan in Mohan 2002; npr. glede preučevanja zdravstvenih neenakosti). Bolj smiselno bi bilo preučevanje učinkov socialnega kapitala na različnih ravneh. Alternativne možnosti so neposredna merjenja društvene aktivnosti na majhnem območju.

Tako je Titmuss (1970; citirano po Mohan in Mohan 2002) zatrjeval, da je razporeditev krvodajalcev ena najboljših možnih meritev kakovosti socialnih odnosov v družbi: podatki o številu krvodajalcev na manjšem območju naj bi predstavljali argumentiran nadomestek za socialni kapital.

Uporabnost njegovega predvidevanja smo preverili v slovenskih razmerah. Ugotavljali smo, na koliko prebivalcev Slovenije pride en darovalec krvi. Na osnovi teoretičnih izhodišč smo predvidevali, da bo na podeželju, kjer naj bi bili ljudje bolj povezani, oziroma naj bi bilo med njimi bolj razširjeno medsebojno zaupanje, več krvodajalcev v manjši prostorski enoti. Podatke smo pridobili na ravni upravnih enot (UE), kjer so tudi sedeži območnih odborov Rdečega križa, ki skrbijo za organizacijo in izvedbo krvodajalskih akcij (podatke zbirajo preko mesečnih poročil Zavoda Republike Slovenije za transfuzijsko medicino in transfuzijskih oddelkov pri splošnih bolnišnicah, kar je v skladu z organizacijsko shemo Rdečega križa Slovenije; Domanović 2007).

Leta 2006 je bilo v Sloveniji 96.395 krvodajalcev. Največ so jih zabeležili v UE Ljubljana (11.154; Zavod RS za transfuzijsko medicino), sledila so večja mesta (Maribor z 8201 darovalcem; Velenje, Kranj, Celje in Škofja Loka so imeli med 3300 in 4500 registriranih odvzemov krvi), manj kot 500 registriranih darovalcev krvi so imele prostorsko in prebivalstveno manjše UE (Logatec, Tržič, Metlika, Hrastnik). Podatke smo primerjali za obdobje treh let (2003-2006), ko smo ob relativno nespremenljivem skupnem številu darovalcev krvi zabeležili velika nihanja znotraj UE. Razlogi so različni: na število darovalcev vpliva velikost UE, število prebivalcev in demografske težnje v UE, tip poselitve, razpoložljivost transfuzijskih oddelkov, oziroma število in lokacija krvodajalskih mest/akcij, pa tudi selitveni tokovi. Statistike beležijo le skupno število oseb, ki so darovale kri, in ne razkrivajo, kolikokrat letno jo je darovala oseba $x$.

Najmanj registriranih prebivalcev na enega krvodajalca oziroma največje število krvodajalcev smo zabeležili v naslednjih UE: Velenje (10,1 prebivalcev UE/krvodajalca), Idrija $(10,6)$, podobno tudi v Škofji Loki, Slovenskih Konjicah, Gornji Radgoni, Postojni, Lenartu in Cerknici $(14,1)$. Najmanj krvodajalcev, oziroma največ prebivalcev na enega krvodajalca, smo evidentirali v UE Domžale $(44,5)$ in Brežice $(43,7)$.

Rezultati delno potrjujejo naše predvidevanje, saj obroč upravnih enot z največ krvodajalci obkroža zgostitveno območje v osrednji Sloveniji. Razvidna so tudi odstopanja (Spodnje Posavje, Zgornja Gorenjska), ki jih lahko pripišemo nekaterim izmed navedenih razlogov, pa tudi širini uporabljenih razredov v kartografskem prikazu. Navedena metoda nam kljub argumentu, da je darovanje krvi izkaz največje stopnje zaupanja med ljudmi, pravzaprav ne pove veliko o kakovosti in načinu povezanosti med ljudmi. Hkrati je zelo vprašljiva tudi primerjava med državami, saj imajo nekatere države sistem plačljivega krvodajalstva, medtem ko le-ta v Sloveniji izhaja iz prostovoljne odločitve. Menimo, da je metoda ugotavljanja števila krvodajalcev kot argumentiranega nadomestka za socialni kapital na današnjem podeželju 
precej nezanesljiva, saj se prebivalci podeželja zaradi različnih razlogov lahko odločijo za darovanje krvi $\mathrm{v}$ mestih, ker $\mathrm{v}$ določenem letu $\mathrm{v}$ njihovem kraju ni bilo krvodajalske akcije ipd. (Kostevc 2008). Seveda je metodološko vprašljiva tudi raven agregiranja dostopnih podatkov.

Slika 1: Število prebivalcev upravne enote v Sloveniji na enega krvodajalca v letu 2006 Figure 1: Number of inhabitants per one blood donor in 2006 in Slovenia (NUTS 4 level)

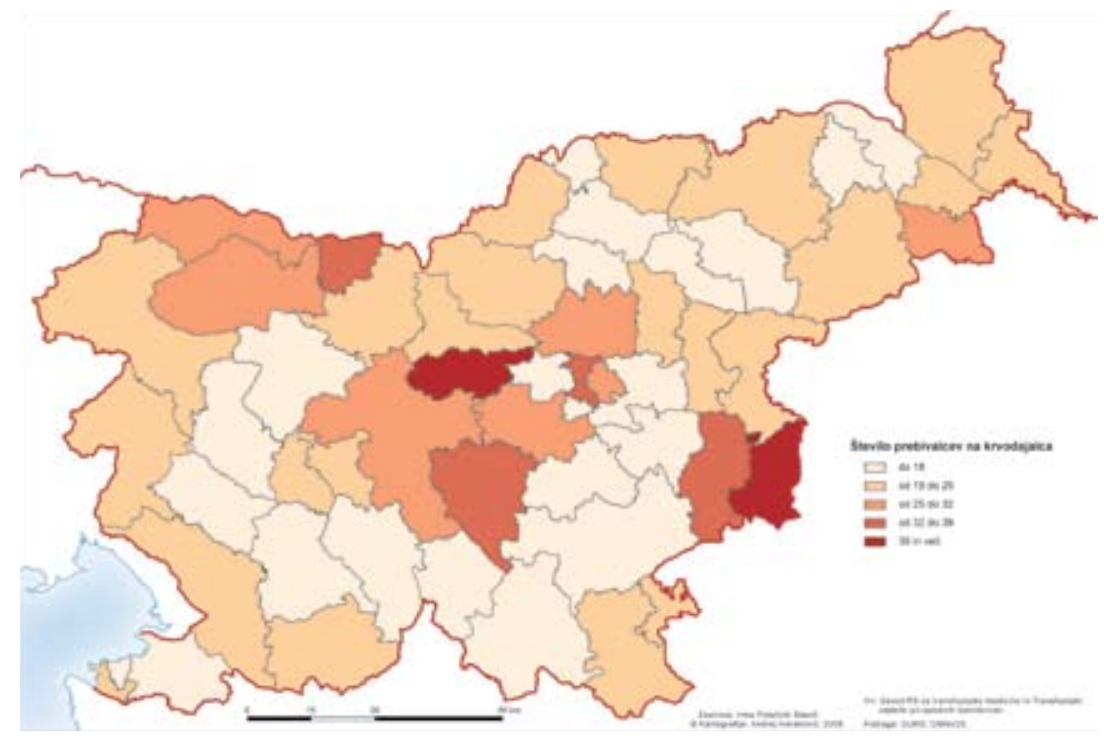

Vir/source: Potočnik Slavič 2008.

Nekatere raziskave (npr. Onyx in Bullen 2000; citirano po Mohan in Mohan 2002) bolj izpostavljajo kvalitativni pristop, ki se usmerja na majhna območja. Tako sta omenjena avtorja podrobno preučevala pet sond v mestnih in podeželskih območjih Avstralije in našla statistično pomembne razlike. Podeželska območja so izkazovala višjo stopnjo vključenosti $\mathrm{v}$ različne skupinske dejavnosti in medsebojne pomoči, tako da so bile stopnje socialnega kapitala večje na podeželju kot v mestih; po drugi strani pa se je pokazalo, da so pri nekaterih vidikih (npr. toleranca raznolikosti) podeželska območja dosegla nižji rezultat.

Maskell (2002; citirano po Mohan in Mohan 2002) trdi, da če je socialni kapital lokalno pogojen, potem ni mogoče razviti uniformiranih meril, ki bi omogočala primerjavo med lokalitetami.

Krishna in Shrader (1999; citirano po Mohan in Mohan 2002) predpostavljata, da če se raven socialnega kapitala ustvarja ločeno za vsako lokaliteto, potem lahko razvijemo instrumente, ki nam bodo pri tem pomagali (npr. profil skupnosti, raziskava gospodinjstev in organizacijskih potez lokalnih skupnosti). 


\section{PREUČEVANJE SOCIALNEGA KAPITALA NA IZBRANIH OBMOČJIH}

Večina raziskav socialnega kapitala vključuje javne podatke na ravni večjih prostorskih enot: običajne so primerjave med državami oziroma večjimi prostorskimi enotami (Janc 2006), redkejše so raziskave na mikrolokalni ravni (Svendsen in Sørensen 2007; Foissner 2000), ki so sicer prostorsko omejene in specifične, vendar dajejo mnogo boljši vpogled v notranje delovanje mikrosistema in pojasnjujejo tudi povezanost navzven.

V raziskavo smo vključili štiri podeželska območja: Suho krajino, Zgornjo Savinjsko dolino, Goriška brda in Brkine, ki jih običajno literatura označuje kot obrobna in se uvrščajo v različne civilizacijske stopnje (Klemenčič 2003), oziroma jih prištevamo k različnim tipom podeželja (Kovačič in sod. 2000).

Preučevanja socialnega kapitala na izbranih območjih smo se lotili na več ravneh:

- pri podjetnikih v obrtno-poslovnih conah smo povpraševali predvsem o povezanosti med podjetji;

- o povezanosti ljudi znotraj občine smo spraševali pristojne v občinskih upravah;

- med lokalnim prebivalstvom smo poizvedovali glede povezanosti med ljudmi;

- $\quad$ pri nosilcih dopolnilnih dejavnosti na kmetiji nas je zanimalo sodelovanje s proizvajalci v okolici, potencialno tudi njihov skupni nastop na trgu.

Glede povezanosti posameznikov in lokalne skupnosti v smislu socialnega kapitala in njegovega pomena za ustvarjanje novih in ohranitev obstoječih delovnih mest ter krepitve lokalnega gospodarstva smo $\mathrm{z}$ anketo med podjetniki (458 podjetij) in nosilci dopolnilnih dejavnosti (64) ugotovili, da je:

- stopnja razvitosti socialnega kapitala med podjetji, ki temelji na opisnih podatkih o oblikah povezovanja med podjetji znotraj cone, med sorodnimi podjetji oziroma o povezovanju podjetij na regionalni ravni, v analiziranih 57 obrtno-poslovnih conah relativno visoka. Iz pridobljenih informacij lahko razberemo zelo pomanjkljivo sodelovanje podjetnikov z občinami in tudi odsotnost poglobljenega podjetniško-razvojnega sodelovanja na ravni bodočih pokrajin;

- večina nosilcev dopolnilnih dejavnosti na kmetiji (in članov njihovih gospodinjstev) je vključena v različna društva in združenja (kmečke zadruge, Združenje turističnih kmetij Slovenije, Združenje ekoloških kmetov, regionalna in lokalna združenja in društva), običajno tudi v več hkrati (npr. strokovna, interesna, kulturno-prosvetna). Za nekatere je to dobra osnova (socialni kapital) za skupen nastop na trgu, saj se običajno pomembnejši akterji posameznih društev združujejo v okviru posamezne blagovne znamke, združenja ali društva.

Podatke o številu in delovanju društev na podeželju smo pridobili iz več virov.

- Iz podatkovne baze BIZI, saj so društva v skladu z zakonodajo registrirana kot poslovni subjekt z naslovom, matično in davčno številko, transakcijskim računom, statutom ipd. Vendar ta baza podatkov razen uradnega naziva in nekaj osnovnih podatkov (šifra opravljanja dejavnosti; običajno nimajo zaposlenih, ker delujejo na prostovoljni podlagi) 
ne posreduje informacij o delovanju društev in njihovem povezovanju znotraj lokalne skupnosti. Imenovana podatkovna baza nam je služila kot raziskovalni okvir glede številčnosti društev.

- Podrobnejše informacije o društvih, njihovem delovanju, članstvu, medsebojnem povezovanju in vpetosti v lokalno skupnost ter vključevanju v širši družbeni prostor ter njihovih problemih smo pridobili na posameznih občinah od direktorjev občinske uprave ali zadolženih za razvoj društev ali zaposlenih na občinskem turistično-informacijskem središču (Kostevc 2008; Janko 2008; Maiti 2008). Informacije smo pridobili z intervjuji in telefonskimi pogovori, oziroma so nam posredovali podatke o višini sredstev, ki jih društva pridobijo iz občinskega proračuna.

- S terenskim delom smo od lokalnega prebivalstva, vključenega v društva, pridobili informacije o živosti društev in njihovi vpetosti v lokalno okolje. Za popolno sliko mreže (ne)formalnih oblik druženja v podeželskih lokalnih skupnosti je najbolje dobiti informacije od članov samih (glede njihovih motivov, pričakovanj in izkušenj), vendar so to časovno in finančno zahtevne oblike dela.

Odločili smo se za modelni prikaz delovanja društev posameznega preučevanega podeželskega območja, ki so financirana iz občinskega proračuna. V obstoječe prikaze nismo vključili delovanja rimskokatoliške cerkve in njenih dejavnosti (pevska, karitativna, molitvena, generacijska ipd.) in političnih strank.

\section{DELOVANJE DRUŠTEV KOT MERILO RAZVITOSTI SOCIALNEGA KAPITALA NA LOKALNI RAVNI}

V občini Žužemberk deluje 42 društev (108 registriranih prebivalcev občine na društvo), pri čemer ima glavno vlogo društvenega inkubatorja Turistično društvo Suha krajina Žužemberk (120 članov, 70 aktivnih), saj je iz njegovih vrst zraslo več društev (najmlajše je Društvo srednjeveških najemnikov). Hkrati je glavni pobudnik najbolj odmevnih in množično obiskanih prireditev, na katerih vključuje tudi druga društva (prostovoljna gasilska društva, kulturna, športna in strokovna društva). Grafično lahko delovanje društev, financiranih iz občinskega proračuna, predstavimo v hierarhični obliki (slika 2).

Največji problem društvene organiziranosti (Kostevc 2008) je ponekod v aktiviranju mladih ali vključevanju večjega deleža lokalnega prebivalstva nasploh, saj nekateri menijo, da je društveno delovanje prvenstveno namenjeno udejanjanju lastnih interesov. Po drugi strani pa aktivnosti društev nakazujejo, da se ljudje radi povezujejo za določene skupne projekte. Propulzivna so tudi nekatera strokovna društva (Društvo vinogradnikov Suha krajina z več kot 100 člani, Konjerejsko društvo Suha krajina s 50-60 člani, Prostovoljno gasilsko društvo v Žužemberku s 120-letno tradicijo in 120 člani, Društvo kmečkih žena Suha krajina - Žužemberk s 100 aktivnimi članicami, Lovska družina Plešivica Žužemberk Z velikim potencialom in 100 aktivnimi člani). Zlasti aktivna in uspešna so tudi v slovenskem merilu športna društva (Odbojkarski klub Žužemberk). V občini Žužemberk obstajajo tudi manjša (Radio klub Žužemberk z manj kot 20 člani) in lokalno osnovana društva (Kulturno društvo Hinje). 
Hierarhična podoba kaže na določeno razvojno zaostajanje v primerjavi z Goriškimi brdi in Mozirjem, kjer so se društva relativno 'enakomerneje porazdelila'. V Suhi krajini je sicer moč prepoznati novo razvojno fazo (veliko število aktivnih društev), a še vedno prihaja premalo pobud od samih prebivalcev, čeprav v zadnjem času sledimo razcvetu različnih civilnih pobud (npr. Ekološko društvo Dvor s 60 člani).

V društva je vključenih 2260 registriranih prebivalcev občine, kar predstavlja polovico prebivalcev. Podatki o članski aktivnosti so zelo različni: ponekod je aktivno celotno društvo (Društvo kmečkih žena), drugod samo delček (v krajevnih odborih Rdečega križa). Značilno je tudi, da je precej ljudi hkrati vključenih v več društev, pri nekaterih je opaziti veliko stopnjo požrtvovalnosti, entuziazem in včasih že kar izgorevanje. Nekatera društva se uspejo tudi poslovno promovirati: Čebelarsko društvo Dvor pri Žužemberku ima tako ob finančni podpori občine dve stojnici pred gradom v Žužemberku. Velike tržne možnosti naj bi imele tudi lovske družine, potencial imajo tudi poznavalci lokalnih posebnosti, tehnik ali starih obrti (npr. lectarka iz Društva kmečkih žena), ki lahko registrirajo osebno dopolnilno delo, vendar poti do podjetništva niso preproste.

\section{Slika 2: Grafični prikaz organiziranosti društev v občini Žužemberk}

Figure 2: Organization of associations in the Municipality of Žužemberk

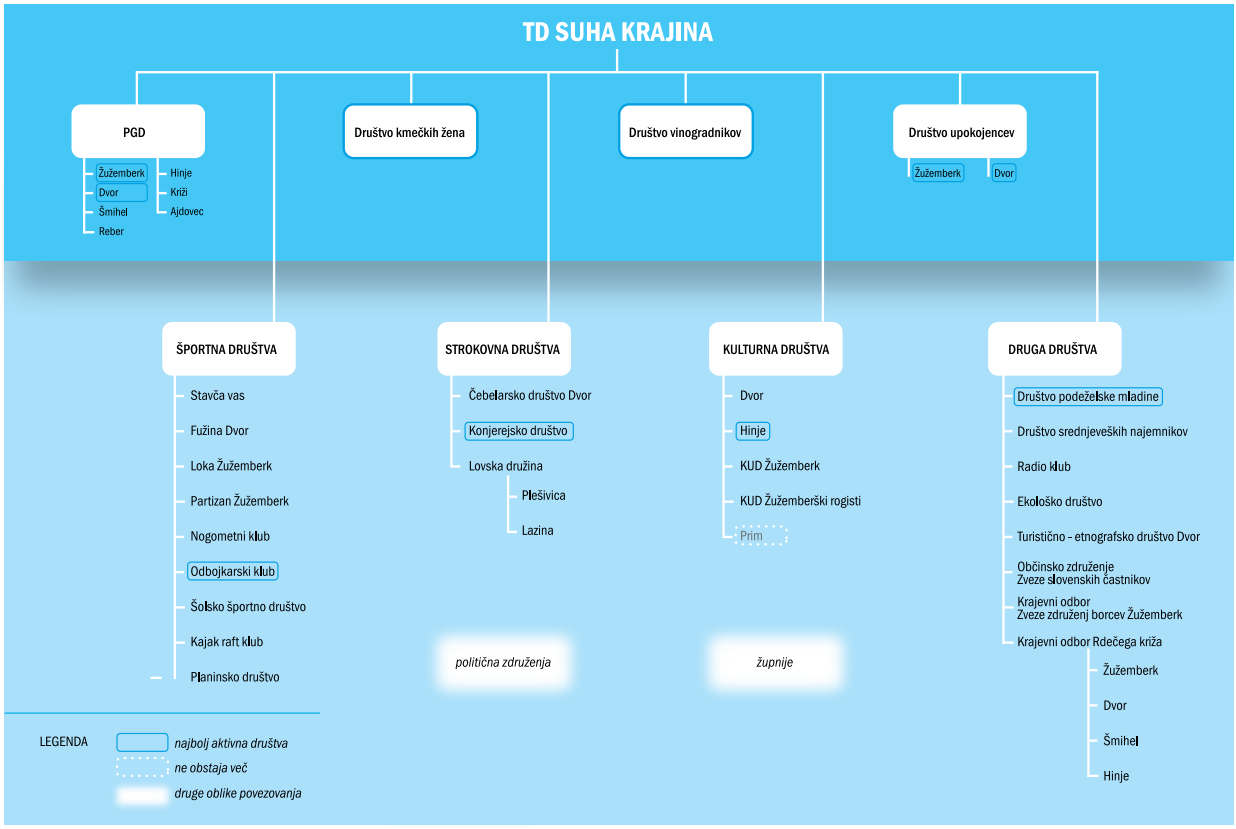

Vir/source: intervjuji, terensko delo, 2008.

V občini Mozirje deluje 52 društev (123 prebivalcev na društvo; podatki o številu prebivalcev so za leto 2006). Po podatkih (niso bili dostopni za vsa društva, zato posredujemo oceno; Janko 2008) je v občini Mozirje aktivnih 2828 članov, kar je slaba polovica vseh 
prebivalcev občine. Glede na središčno lego občine, ki je hkrati tudi središče upravne enote, je razumljiva večja zgostitev tako lokalnih kot tudi regionalnih/nacionalnih ustanov oziroma društev (Društvo zgornjesavinjskih diabetikov, Zgornjesavinjsko društvo invalidov, Območna izpostava javnega sklada RS za kulturne dejavnosti Mozirje, Kmetijsko-gozdarska zbornica Slovenije - KGZ Celje ipd.). Njihovo organiziranost smo prikazali s kombinacijo treh načinov:

- društva smo razvrstili glede na vrsto njihove dejavnosti (turistična, športna, kulturna, generacijska, strokovna ipd.);

- njihovo pomembnost smo v modelu nakazali tako, da smo najbolj aktivna, t.j. nosilno-povezovalna društva, občrtali (Prostovoljno gasilsko društvo Mozirje, Društvo upokojencev Mozirje, Kulturno društvo Godba Zgornjesavinjske doline, Kulturno društvo Jurij, Ekološko hortikulturno društvo Mozirski gaj, Društvo za ohranjanje kulturne dediščine - Pust mozirski, Turistično društvo Mozirje, Športno društvo Mozirje itd.; slika 3);

- ker gre za veliko društev in pravega sistema delovanja ne moremo razbrati in preprosto prikazati, smo ugotavljali, katera društva odločilno prispevajo pri najpomembnejših dogodkih v občini Mozirje (pustovanje in Mozirski gaj); ponovno izstopajo društva, ki imajo vlogo mostiščenja in prepletanja (turistično-etnološka društva, gasilci ipd.).

\section{Slika 3: Delovanje društev v občini Mozirje}

Figure 3: Organization of associations in the Municipality of Mozirje

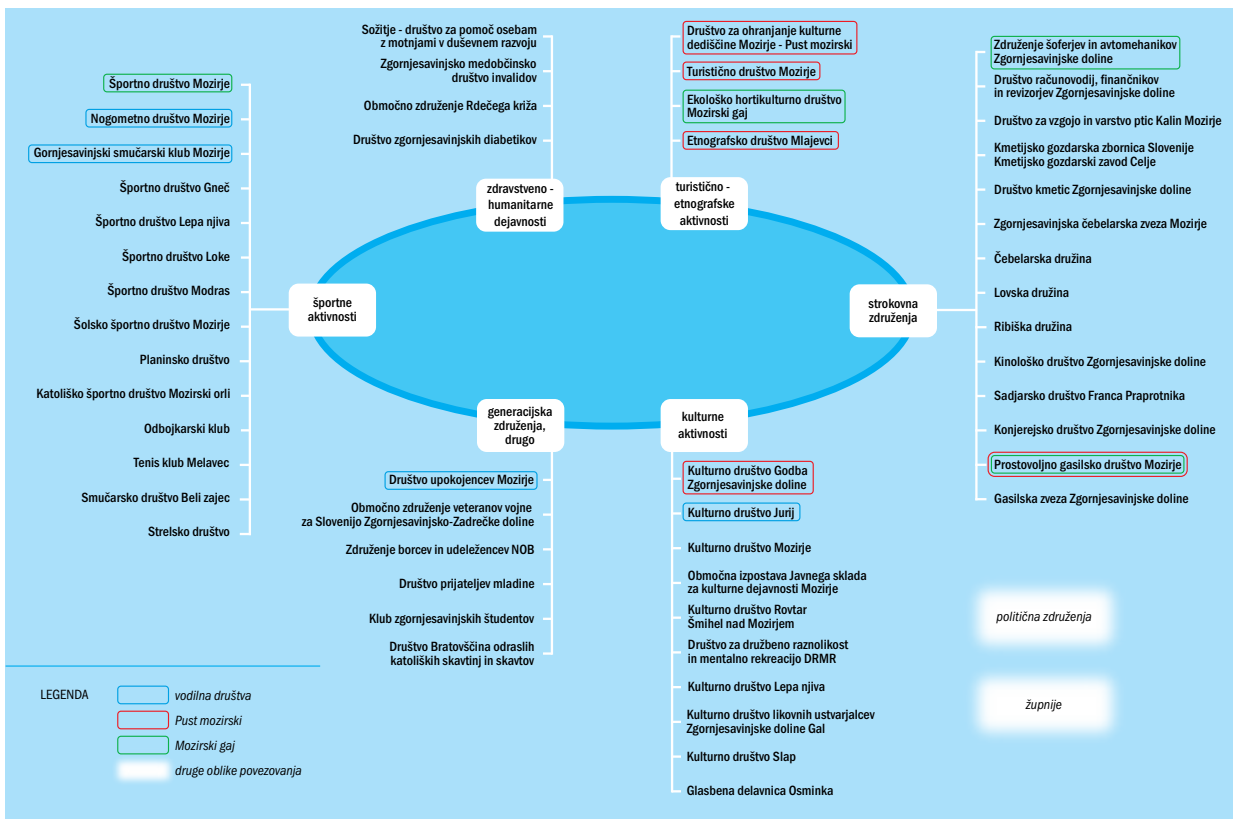

Vir/source: intervjuji, terensko delo, 2008. 
V občini Brda deluje 34 društev (169 registriranih prebivalcev Brd na društvo; popis 2006), katerih aktivnost, pomembnost in povezanost $\mathrm{v}$ lokalni skupnosti smo grafično prikazali v obliki koncentričnih krogov (slika 4).

- Društva, ki predstavljajo središčni del (Mešani pevski zbor Rado Simoniti, Moški pevski zbor Srečko Kumar, Pihalni orkester Brda, Kolesarsko društvo Brda, Prostovoljno gasilsko društvo Dobrovo, Društvo kmečkih žena; Maiti 2008), spadajo med najaktivnejša glede števila prireditev, ki jih vodijo ali na njih sodelujejo. Omenjena društva so pomembna tudi zaradi številčnosti članov in števila ljudi iz lokalne, regionalne, državne ali mednarodne sredine, ki prisostvujejo njihovim dejavnostim, saj delujejo tudi kot promotorji Brd, Bricev in njihove identitete. Ta društva so tudi po mnenju informatorjev nosilna za krepitev in razvijanje društvenega, prostovoljnega, kulturnega, športnega in drugega življenja v lokalni skupnosti.

- Z odmikom od središča prikazujemo društva, katerih vloga je še vedno zelo opazna, saj so pomemben partner pri prepoznavnih dejavnostih v Brdih (dnevi promocije češenj, poezija in vino ipd.), ki so odmevne znotraj, a tudi izven lokalne skupnosti (Društvo Medana, Planinsko društvo Brda, Društvo ljubiteljev rebule in oljčnega olja ipd.).

- Društva, ki so financirana iz občinskega proračuna in so v zunanjem delu modela, običajno predstavljajo način lokalne promocije (Gledališka skupina Neblo), so izraz močne ciljne aktivnosti znotraj posameznega naselja (Klub malega nogometa San Martins) ali ozke socialne, starostne ali interesne skupine (Lions klub, Jeep club Brda, Mažoretna skupina, Lovska družina).

Za tovrstno predstavitev dejavnosti smo se odločili, ker je struktura društvenega delovanja postavljena povezovalno, dopolnjevalno, navezovalno, spodbujajoče: društva imajo 2500 članov, kar pomeni, da je vsaj formalno več kot $40 \%$ prebivalcev Brd vključenih v eno izmed društev (podatki niso natančni, saj je precej ljudi v več društvih hkrati; Maiti 2008), tretjina je aktivnih. Nekatera interesna društva (npr. Društvo vinogradnikov Vipolže, ki je zdaj konzorcij) so že prerasla okvirje prostovoljnih društev in so drugače registrirana.

Iz modelne zasnove je razvidna dobra povezanost, ki navaja k sklepanju na obstoj krepkega socialnega kapitala: predvidevamo, da medsebojne povezave, ki temeljijo na medsebojnem poznavanju, sodelovanju in zaupanju ustvarjajo tudi predpogoje za aktivno gospodarsko sodelovanje. Ker je tudi v občini Brda precej ljudi vključenih v več dejavnosti hkrati, to praktično pomeni, da se na več dejavnostih srečujejo isti ljudje; zato predpostavljamo, da so te vezi (kljub občasnim negativnim primerom) še močnejše, kar lahko potrdimo tudi z aktivno promocijo nekaterih podjetnikov-vinarjev preko društev.

Potrebno je poudariti, da ima članstvo $v$ društvih in njihovo delovanje v Sloveniji pravzaprav že dolgo tradicijo in je zlasti na obmejnih, odmaknjenih in podeželskih območjih (poleg šole) pomemben motor celotnega družbenega utripa. Ker gre za prostovoljne dejavnosti, tudi ne moremo v popolnosti zagotoviti, kakšen bo njihov razvoj v prihodnje, saj je veliko stvari odvisnih od posameznikov, njihovih potencialov, medsebojnega razumevanja, medgeneracijskih prehodov in splošnega odnosa družbe do tovrstnih dejavnosti. Zlasti mladi se redko ali redkeje vključujejo $v$ takšne oblike organiziranosti in krepitve socialnega kapitala na podeželju. Za njih je zlasti pomemben osebni motiv, družinski zgled, medsebojni odnosi ali podoba nekega društva $v$ širši skupnosti. 
Slika 4: Povezanost društev v občini Brda

Figure 4: Organization of associations in the Municipality of Brda

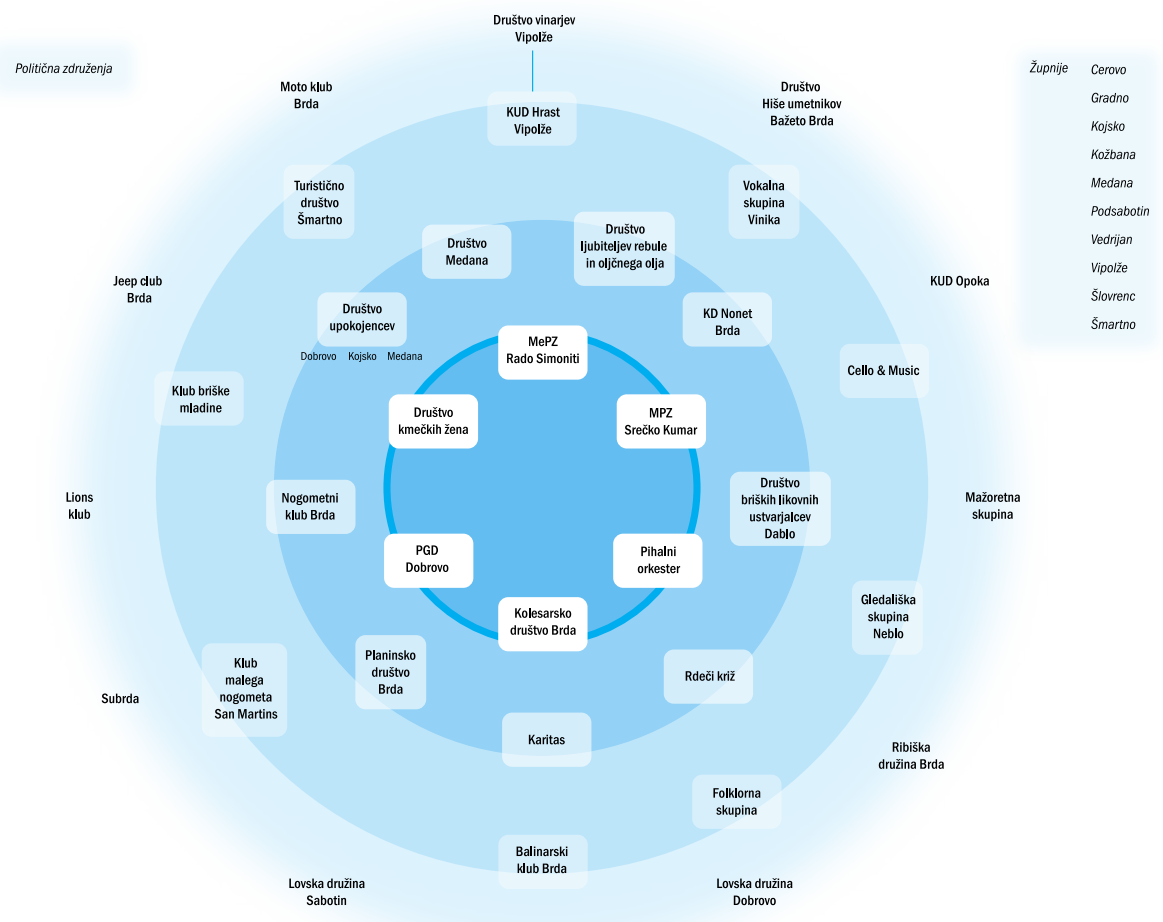

Vir/source: intervjuji, terensko delo, 2008.

Uspehe posameznih društev gre velikokrat pripisati osebnemu angažiranju predsednika ali aktivnih članov društva. Težko je posploševati, kolikšno je optimalno število članov društva, saj so dejavnosti nekaterih društev bolj priljubljene in odmevne kot druge, npr. Društvo kmečkih žena ima 70 članic (50 aktivnih), Moški pevski zbor Srečko Kumar 16 članov (vsi so aktivni), Društva upokojencev Dobrovo, Kojsko in Medana pa imajo več kot 1000 registriranih članov. Nekatera društva so v nastajanju (npr. Folklorna skupina), druga so še mlada (Subrda-društvo potapljačev; Mažoretna skupina) ali imajo zagotovljen podmladek (Prostovoljno gasilsko društvo Dobrovo). Ponekod imajo probleme s podmladkom (lovski družini), nekatera društva so tradicionalna (Balinarski klub), lahko vključujejo celotno naselje (Društvo ljubiteljev rebule in oljčnega olja v Višnjeviku) ali imajo člane in aktivnosti vsepovsod v Brdih (Rdeči križ, Karitas, Planinsko društvo Brda), delujejo regionalno ali tudi čezmejno (koncerti in sodelovanje s sorodnimi društvi v Italiji - Pihalni orkester Goriška brda, KUD Hrast Vipolže, Vokalna skupina Vinika, Nogometni klub Brda ipd.). 


\section{KONČNE UGOTOVITVE}

Navkljub nekaterim omejenim pojasnjevalnim zmožnostim uporabljene metode smo uspeli z njeno uporabo analizirati stopnjo razvitosti socialnega kapitala na lokalni ravni.

Suha krajina je v zgodnji fazi prepoznavanja in (conalne) krepitve endogenih razvojnih potencialov; tovrstni zaostanek je posledica zapletenih in medsebojno pogojenih razlogov. $\mathrm{V}$ zadnjem desetletju sledimo intenzivnemu prebujanju podjetništva, okrepljenemu delovanju društev, postopno večji prepoznavnosti in sodobnemu vrednotenju relativno tradicionalne podeželske pokrajine, ki je v 20. st. doživljala polkolonialno odvisnost. Zaradi negativnih izkušenj in demografske erodiranosti je lokalno prebivalstvo, ki sicer ima želje, nima pa dovolj zmožnosti za hitrejše, velikopotezno in nadregionalno prepoznavno pozicioniranje Suhe krajine, težko vzpodbuditi k lastnim pobudam.

Zgornja Savinjska dolina je že na poti usmerjene rabe endogenih razvojnih potencialov (Potočnik Slavič 2008). Baza regionalnih virov je specifična in velika, inovativnost v njihovem izkoriščanju in širitvi je tudi že prisotna. Na drugi strani ima prebivalstvo specifična znanja, dobro (mrežno) je organizirano in povezano, se aktivno vključuje v različne oblike društvenega življenja in sodeluje pri prepoznavnih prireditvah, izrazit je občutek lokalne pripadnosti.

Goriška brda so primer geografsko zaokroženega območja, ki zaradi različnih vzrokov krepi endogene razvojne potenciale. Večji del razvoja temelji na kmetijstvu, ki se mu ob bok intenzivno in uspešno postavlja turizem, ostale panoge so v funkciji spodbujanja oziroma krepitve kapitala, potrebnega za obe nosilni gospodarski dejavnosti. Na širše regionalne in mednarodne trge vstopa s pozitivno podobo visoko kakovostne in specializirane podeželske turistične destinacije. Razvite so čvrste lokalne mreže in lokalna identiteta. Zaradi velikega interesa za vzpostavitev različnih dejavnosti za krepitev lokalnega gospodarstva obstaja $\mathrm{V}$ Brdih velik konfliktni potencial in nevarnost prevlade interesov invazivnega kapitala ter posledično velike obremenitve podeželja in možnost njegove degradacije.

Brkini, ki so se zaradi upravno-administrativne razdrobljenosti, pomanjkanja lokalne identitete in neprepoznavnosti izkazali kot zanimivo, a manj primerno območje za preučevanje razvitosti socialnega kapitala, so primer ne dovolj medsebojno povezane lokalne skupnosti, saj je njihov demografski kapital dolga stoletja predstavljal zalogo večjim središčem. Brkini sami zaradi večstoletne zunanje odvisnosti niso razvili ustreznih endogenih razvojnih struktur. Razvojno smiselne in na tradicijo vezane lokalne pobude večinoma nimajo dovolj moči za močnejši prodor, a pomenijo iskrico (celična zasnova) za krepitev oživljanja podeželja v smislu endogenega razvojnega pristopa.

\section{SKLEP}

Socialni kapital je istočasno gospodarski, sociološki, politični in geografski koncept. Sestavljajo ga mreže sodelovanja, ki temeljijo na rednih povezavah 'na štiri oči' in na zaupanju. Tako povezovanje nudi udeleženim, t.j. 'lastnikom socialnega kapitala', dve prednosti na mikro ravni: medsebojno vzajemno storitev ter informacije in družbene prednosti (npr. zaupanje, prepoznavnost in nižja stopnja kriminala). Sredstvo za izgradnjo socialnega kapitala 
je organizacijski kapital, ki vključuje organizacijske strukture v vsakodnevnem življenju (npr. delovni procesi, podjetniška organizacijska kultura, organizacijski načini, ki pripadajo lokalni skupnosti: npr. prostovoljne dejavnosti; Svendsen in Sørensen 2007). Če se socialni kapital ustvarja z interakcijo med posamezniki, potem je potrebno reči, da se kakovost odnosov med posamezniki oblikuje odvisno od okolja, v katerem živijo. Če vključevanje $\mathrm{v}$ različne oblike društvenega življenja prispeva k oblikovanju socialnega kapitala, potem obstajajo dobri razlogi, da pričakujemo geografske razlike v socialnem kapitalu. Nekateri (Mohan in Mohan 2002) celo govorijo o geografiji socialnega kapitala.

Socialni kapital ima domnevno pozitivne učinke na posameznike (podpira boljšo zdravstveno, socialno interakcijo, povečuje verjetnost za uspešno iskanje dela, ustvarja ustrezno okolje za podjetništvo) in skupnosti (na splošno spodbuja gospodarski razvoj s tem, da omogoči razpoložljivost določenih virov, ki sicer v drugačnih okoliščinah ne bi bili na razpolago - npr. mikrokreditne sheme, skupna oprema). Ne morejo si ga lastiti ne posamezniki ne posamezne skupine.

Kljub povečanemu zanimanju za socialni kapital obstaja nesoglasje glede rabe tega koncepta, kar pa ni preprečilo, da ga politiki in ustanove ne bi prevzele. Potrebno se je zavedati, da je izgradnja socialnega kapitala $v$ večini primerov le sestavina širše razvojne pobude. Tako je socialni kapital vedno povezan z ali odvisen od specifičnih razvojnih okoliščin, preučevanih območij in ciljnih skupin. Bolj pogosto se uporablja kot metoda in ne kot namen same politike.

V sodobnem času in na heterogenem podeželju verjetno ne obstaja ena, splošno veljavna in uniformirana metoda merjenja socialnega kapitala. Campbell (1993; citirano po Mohan in Mohan 2002) tako ugotavlja, da so tradicionalne oblike prostovoljstva žive in dobro delujejo na nekaterih področjih (predvsem v srednjem razredu, cerkvi in ženskih organizacijah) in da ne moremo govoriti o splošnem, ampak o lokaliziranem upadu socialnega kapitala.

Za razvoj podeželja ima socialni kapital pomembno vlogo. Zaradi nedostopnosti podatkov se je bilo pri raziskavi potrebno osredotočiti na formalne oblike povezovanja, ki so pomemben kazalec socialnega kapitala na slovenskem podeželju. Razvitost socialnega kapitala je odvisna od medsebojnega učinkovanja človeškega, gospodarskega in okoljskega kapitala ter specifičnih geografskih, zgodovinskih, političnih in razvojnih dejavnikov, osnovna izhodišča mu daje splošen družbeno-gospodarski razvoj. Raziskava je pokazala, da so lokalna društva pomemben dejavnik lokalnega razvoja oziroma merilo razvitosti socialnega kapitala. Glede na vrsto in število društev, delež včlanjenega prebivalstva ter sodelovanja med društvi lahko opredelimo več tipov organiziranosti socialnega kapitala: hierarhični (Suha krajina), nosilnopovezovalni (Zgornja Savinjska dolina), koncentrični (Goriška brda). Na demografsko izčrpanih območjih obstajajo le posamezni elementi socialnega kapitala, ki sami zase ne morejo poskrbeti za učinkovit lokalni razvoj (npr. Brkini). Tako je socialni kapital mrežno razvit v Goriških brdih in Zgornji Savinjski dolini, določeno razvojno zaostajanje je opazno v Suhi krajini, medtem ko se nastavki za njegov razvoj v Brkinih (pre)počasi oblikujejo.

\section{Viri in literatura}

Domanović, D. 2007: Zbiranje podatkov o krvodajalcih v Republiki Slovenije. Zavod RS za transfuzijsko medicino. Ljubljana (september 2007). 
Foissner, P. 2000: Endogene Entwicklung in peripheren Regionen: Möglichkeiten der Aktivierung endogener Potenziale in der Region Vorpommern. Raumforschung und Raumordnung 58, 4. Köln.

Janc, K. 2006: Human and social capital in Poland - Spatial diversity and relations. V: Komornicki, T., Czapiewski, K. (ur.). Europa XXI, 14. Core and peripheral regions in Central and Eastern Europe. Warszawa.

Janko, J. 2008: Delovanje društev v občini Mozirje. Občina Mozirje (marec 2008).

Klemenčič, M. M. 2003: Civilizacijske razvojne stopnje in razvojni problemi obrobnih območij v Sloveniji. Dela 19. Ljubljana.

Kostevc, V. 2008: Delovanje društev v občini Žužemberk. Občina Žužemberk (5.3.2008).

Kovačič, M., Gosar, L., Fabijan, R., Perpar, A., Gabrovec, M., Jakoš, A. 2000: Razvojno-tipološka členitev podeželja v Republiki Sloveniji. Ljubljana.

Maiti, K. 2008: Delovanje društev v občini Brda. TIC Brda (april 2008).

Mandl, I., Oberholzner, T., Dörflinger, C. 2007: Social capital and job creation in rural Europe. European foundation for the improvement of living and working conditions. Wien.

Medmrežje 1: BIZI, podatkovna baza, 2006. http://www.bizi.si (citirano 20.2.2008).

Medmrežje 2: BIZI, podatkovna baza, 2007. http://www.bizi.si (citirano 5.6.2008).

Medmrežje 3: Statistični urad R Slovenije, 2006-2008. http://www.stat.si/ (več citatov).

Mohan, G., Mohan, J. 2002: Placing social capital. Progress in human geography 26, 2. London.

Moseley, M. J. 2003: Rural development. Principles and practice. London.

Potočnik Slavič, I. 2008: Endogeni razvojni potenciali podeželja. Doktorska disertacija, Oddelek za geografijo, Filozofska fakulteta Univerze v Ljubljani. Ljubljana.

Putnam, R. D. 1993: Making democracy work: civic traditions in modern Italy. Princeton.

Svendsen, G. L. H., Sørensen, J. F. L. 2007: There's more to the picture than meets the eye: Measuring tangible and intangible capital in two marginal communities in rural Denmark. Journal of rural studies 23. Oxford.

\section{SLOVENIAN RURAL AREAS AND SOCIAL CAPITAL}

\section{Summary}

Social capital is simultaneously an economic, sociological, political and geographical concept. Social capital is alleged to have beneficial effects on both individuals (promoting better health, social interaction, increasing probability of successful job search, providing a favorable climate for entrepreneurship) and communities (generally, stimulating economic development by making certain resources available that otherwise would be lacking (e.g. microcredit schemes or sharing of capital equipment)). It cannot simply be appropriated by individuals or particular groups.

Despite conceptual and methodological problems, scholars have not rejected social capital surveying. On the contrary, they are interested in it because it apparently offers the power to explain uneven development at various scales, understanding the comparative performances of governments and accounting for spatial variations in health experience 
(Mohan and Mohan 2002). Over the past decade, social capital has become an important analytical concept and policy tool within development studies. Therefore, social capital is always connected to or depends on specific development circumstances, surveyed areas/ localities and target groups.

Contemporary heterogeneous, multifunctional, hybrid and fluid rural areas do not concede only one, general and uniformed method of social capital measurement; ubiquitous are various forms and development levels of social capital. Campbell (1993; cv. Mohan and Mohan 2002) states that traditional forms of voluntarism are alive and well in some fields (mostly within the middle class, church and women organizations) and therefore we are not allowed to talk about generalized, but localized decrease in social capital.

Social capital has an important role for rural development, it comprises different local/ regional forms initially based on general socio-economic development. Social capital is comprised by networks of co-operation, based on regular 'eye-to-eye' meetings, norms and trust. Our research pointed out that local associations are important factor for local development and measuring tool of social capital development. Based on sets and number of associations, number of active participants (relative to total population figure), and on co-operation amongst associations we are able to define following types of social capital organization: hierarchical (Suha krajina), pillar-bridging (Upper Savinja Valley) and concentric (Goriška brda). Economically and demographically eroded areas have few elements of social capital, they are powerless for effective endogenous local development (for example Brkini).

Our survey in Slovenian rural areas emphasizes different levels of social capital development (based on official data and field survey of associations at municipality level):

- good established and active networking in Goriška brda (wine-growing border region with Italy) and Upper Savinja Valley (remote mountainous rural area with huge natural amenities) with large local community capacity for social capital development;

- bounded local community networking in Suha krajina region (karst, peripheral and eco-nomically underdeveloped area) that has experienced its renaissance in the last two decades, but still keeps the hierarchical structure;

- modest local community networking and social capital building in Brkini region (hilly and mountainous, demographically eroded) where cellular forms of social interaction occur. 